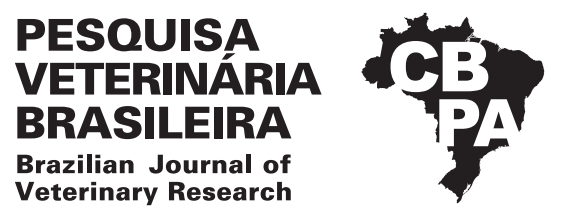

Pesq. Vet. Bras. 39(5):304-307, May 2019 DOI: 10.1590/1678-5150-PVB-6086

Original Article

ISSN 0100-736X (Print) Livestock Diseases

ISSN 1678-5150 (Online)

\title{
Osseous malformation in calves and its relationship with ingestion of apple pomace in pregnant cows ${ }^{1}$
}

\author{
Nathalia S. Wicpolt ${ }^{2}$ and Aldo Gava ${ }^{2 *}$ (D)
}

\begin{abstract}
Wicpolt N.S. \& Gava A. 2019. Osseous malformation in calves and its relationship with ingestion of apple pomace in pregnant cows. Pesquisa Veterinária Brasileira 39(5):304-307. Laboratório de Patologia Animal, Departamento de Medicina Veterinária, Centro de Ciências Agroveterinárias, Universidade do Estado de Santa Catarina, Avenida Luiz de Camões 2090, Lages, SC 88520-000, Brazil. E-mail: aldo.gava@udesc.br

Three outbreaks of osseous malformation in claves born of cows fed apple pomace throughout pregnancy are described. This study was carried out from historical surveys on properties where apple pomace was used in cattle feeding. The outbreaks occurred in the municipalities of Lages, Santa Catarina state, from 2007 to 2012, and Ipê, Rio Grande do Sul state, from 2011 to 2012 . These calves presented bone deformity characterized mainly by arthrogryposis and chondrodysplasia of the anterior limbs. At necropsy, the observed changes were restricted to bending and thickening of the anterior limbs and skull. Microscopically, a disorganized, irregular, misaligned hypertrophic zone was observed in the humeral-radio-ulnar joints, in addition to absence of growth zone, thin bone trabeculae, and closed epiphyseal growth plate.
\end{abstract}

INDEX TERMS: Osseous malformation, calves, ingestion, apple pomace, pregnant cows, cattle, pathology.

\begin{abstract}
RESUMO.- [Malformações ósseas em bezerros e sua relação com a ingestão de bagaço de maçã por vacas prenhes.] Descrevem-se 3 surtos de malformações ósseas em bezerros, nascidos de vacas prenhes alimentadas com bagaço de maçã. Estudos foram realizados a partir de levantamento de históricos em propriedades onde bagaço de maçã foi utilizado na alimentação de bovinos. Os surtos ocorreram nos municípios de Lages em Santa Catarina, de 2007 a 2012, e Ipê em Rio Grande do Sul, de 2011 a 2012. Dentre 20 e 69,2\% dos bezerros apresentavam deformidade de membros, caracterizada principalmente por membros anteriores curvos e curtos. Na necropsia as alterações observadas restringiam-se ao encurvamento e engrossamento dos membros e do crânio. Microscopicamente nas articulações úmero-radio-ulnar, foi observado zona hipertrófica desorganizada, irregular e sem alinhamento, além de ausência da zona de crescimento e trabéculas ósseas finas e placa epifisária fechada.
\end{abstract}

\footnotetext{
${ }^{1}$ Received on November 25, 2018.

Accepted for publication on December 19, 2018.

Part of Doctoral Dissertation of the first author. Financed by FUMDES through scholarship.

${ }^{2}$ Laboratório de Patologia Animal, Departamento de Medicina Veterinária, Centro de Ciências Agroveterinárias, Universidade do Estado de Santa Catarina, Avenida Luiz de Camões 2090, Conta Dinheiro, Lages, SC 88520-000, Brazil. *Corresponding author: aldo.gava@udesc.br
}

TERMOS DE INDEXAÇÃO: Malformação óssea, bezerros, ingestão, bagaço de maçã, vacas prenhes, bovinos, patologia.

\section{INTRODUCTION}

In the south region of Brazil, apples (Malus spp.) are grown on a large scale, and pomace is the main by-product generated in the agroindustry, consisting of skin and flesh (94.5\%), seeds (4.4\%), and stem (1.1\%) (Kennedy et al. 1999), used as an alternative energy source in the feeding of ruminants, mainly bovines (Manterola et al. 1999). Consumption of this by-product by cows during pregnancy may be associated with the birth of calves with osseous malformation indicative of arthrogryposis and chondrodysplasia.

The conditions under which apple pomace can produce such malformations are still unknown. Arthrogryposis is characterized by permanent muscle contracture of the limbs in flexion or extension and by muscular atrophy (Schild 2007), and it is generally bilateral and symmetrical (Zachary 2018). Chondrodysplasia (dwarfism) is a congenital malformation hereditarily transmitted in most cases, characterized by the abnormal development of interstitial growth cartilage (endochondral ossification) of the long bones, resulting in abnormal and diminished longitudinal growth of the bones (Latter et al. 2006, Thompson 2007). Some authors refer to these syndromes as part of a set of abnormalities named 
congenital chondrodystrophy of unknown origin (CCUO) (White et al. 2010a, 2010b, White \& Windsor 2012).

This study aimed to report the occurrence of three outbreaks of osseous malformation in calves born of cows fed apple pomace and describe their epidemiological, clinical and pathological factors.

\section{MATERIALS AND METHODS}

An epidemiological survey was conducted in three farms, with a history of malformation in calves born of cows fed apple pomace during pregnancy, located in the municipalities of Lages, Santa Catarina state, and Ipê, Rio Grande do Sul state. Three affected calves were necropsied and had tissue samples collected from the central nervous system, heart, lung, kidney, liver, spleen, rumen, reticulum, omasum, abomasum, intestine, skeletal muscle, and bone, and fixed in $10 \%$ formalin for histological examination. The material was routinely processed, stained using the hematoxylin-eosin (HE) technique (Prophet et al. 1992), and assessed by optical microscopy.

\section{RESULTS}

The outbreaks occurred in three rural properties: two located in the municipality of Lages, Santa Catarina state (Properties 1 and 2) and one in the municipality of Ipê, Rio Grande do Sul state (Property 3). In the three outbreaks, the cows were raised for beef and were of the following breeds: crossbred cows x Charolais bull in Property 1 , crossbred cows x Limousin bull in Property 2, and Red Angus cows and bull in Property 3. In the three farms, the cows grazed on native pasture and were supplemented with apple pomace at a dose of 20-30kg/animal/day. In Property 1, apple pomace was first fed to cows in 2007 and, according to the owner, since it began to be used for a herd of 30 cows, $15-20 \%$ of the calves born each year presented malformations. In 2012, 19 calves were born with malformations, five died, and one was necropsied. In Property 2, apple pomace was provided to six cows throughout pregnancy. Of the six calves born of these cows, three showed serious osseous malformations. Two of these calves died and one was euthanized for necropsy. In Property 3, in 2011, of the 13 cows that received apple pomace during pregnancy, 9 calves were born with osseous malformation, 5 of which were born dead. In 2012, nine claves with malformation were born of 17 cows. At the same property, a second herd of cows that did not receive apple pomace in the diet, but were kept in a nearby area, bred normal calves. According to reports obtained in the three properties, the disease appeared after introduction of apple pomace in the feed. The apple pomace was stored in silo and, after fermenting for a week, was gradually fed to the cattle in the trough until reaching the dose of 30kg/animal/day. The owners of Properties 1 and 3 reported that they exchanged the mating bull of the cows, but the problem persisted.

The main changes observed in the calves were similar in the three properties. They were characterized by enlarged humeral-radio-ulnar joints (Fig.1). Some calves, in addition to changes in the limbs, had a disproportionate skull and short muzzle (Fig.2). Some calves could not move and generally died a few days after birth and/or were euthanized. Those born with discrete lesions, although bending of the anterior and posterior limbs disappeared, showed proportional dwarfism after a few months. Necropsy findings were restricted to the bone system, which presented curved forelimb bones of enlarged diameter (Fig.3A,B). Histological examination showed disorganized, irregular and misaligned hypertrophic zone, thin bone trabeculae, and closed epiphyseal plate (Fig.4).

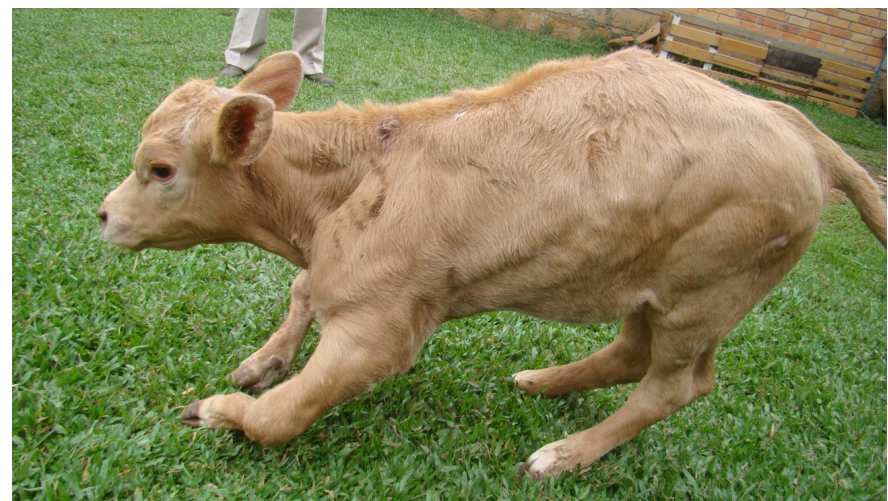

Fig.1. Natural poisoning with apple pomace. Calf with shortened and curved forelimbs and enlarged joints.

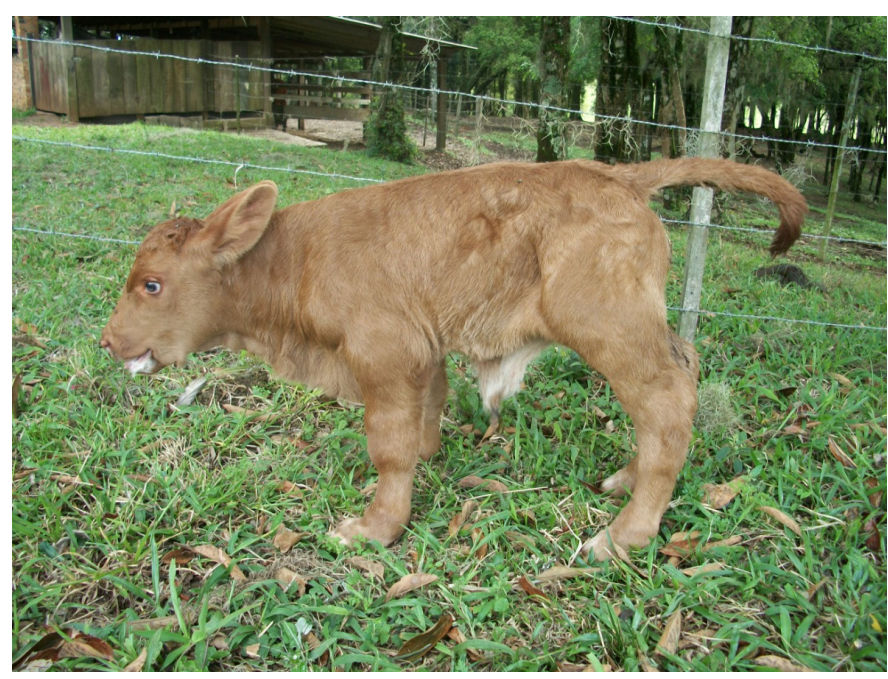

Fig.2. Natural poisoning with apple pomace (Property 3). Calf with head disproportionate to the body (larger) and short muzzle. Curved and shortened anterior and posterior limbs and enlarged joints.
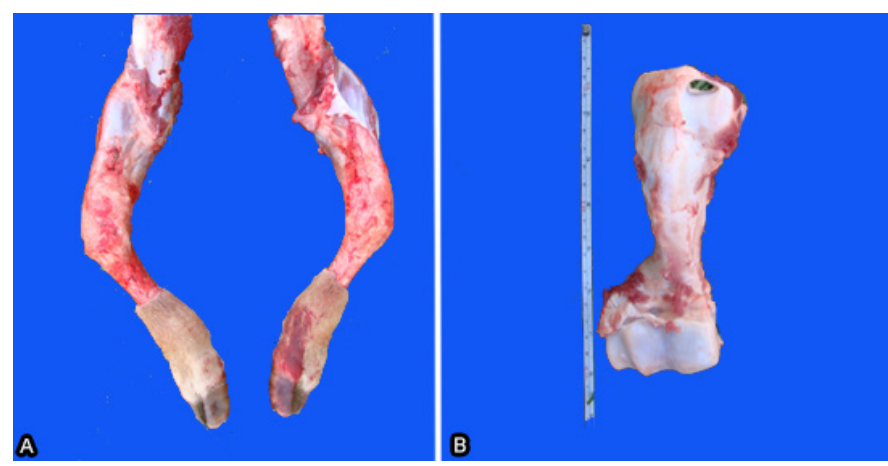

Fig.3. Natural poisoning with apple pomace. Calf necropsy (Property 2). (A) Curved bones of the forelimbs and (B) humerus with enlarged diameter. 


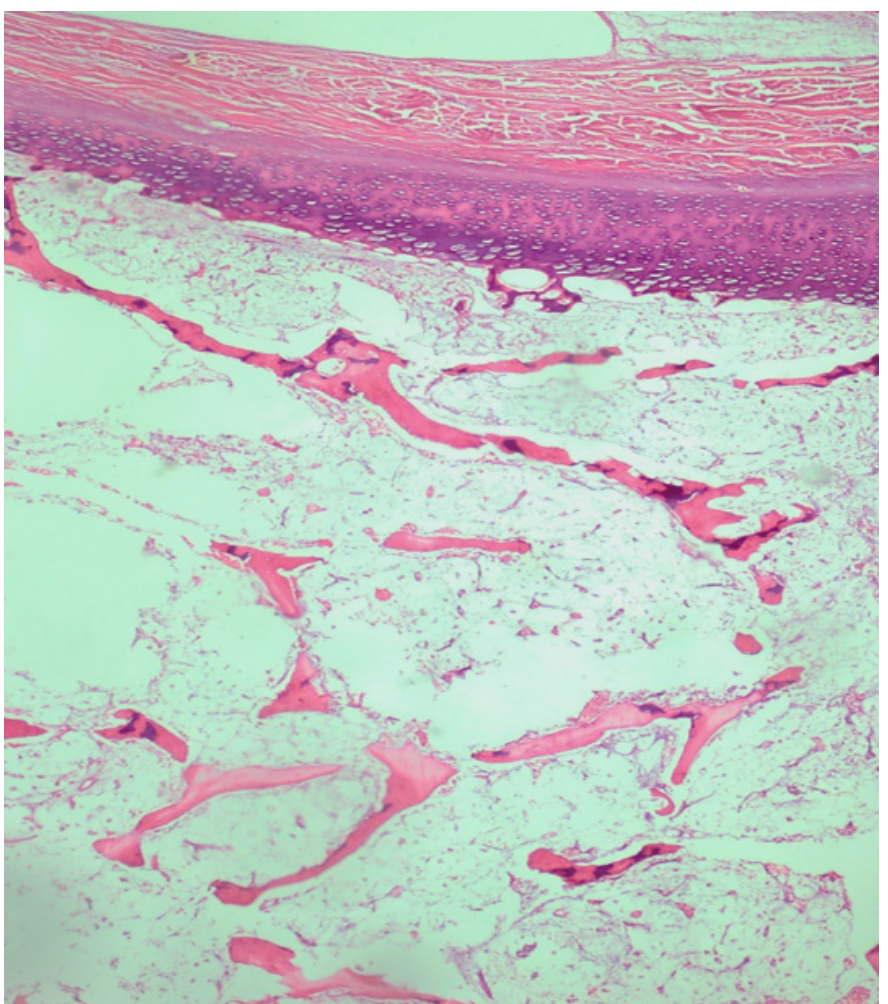

Fig.4. Natural poisoning with apple pomace. Disorganized, irregular and misaligned hypertrophic zone, thin bone trabeculae, and closed epiphyseal plate in humerus. HE, obj.10x.

\section{DISCUSSION}

Diagnosis of osseous malformations in calves associated with ingestion of apple pomace by pregnant cows was based on epidemiological and macro- and microscopic clinical findings. In the present study, after introduction of apple pomace in feed, most of the cows bred calves with malformations. In the assessed properties, occurrence of the disease coincided with the use of apple pomace at expressive doses $(25-30 \mathrm{~kg} /$ animal/day). Absence of abortions and persistence of the disease after the exchange of the mating bull reinforces the hypothesis that apple pomace was the cause of osseous malformation. The use of apple pomace was interrupted in all of the farms, and the disease did not occur within the following two years.

Most of the times, cases of osseous malformation are sporadic and of difficult etiology. They may be of hereditary origin, transmitted by autosomal, recessive gene in Holstein Friesian cattle (Marcolongo Pereira et al. 2010), or associated with infectious agents such as the bluetongue (BTV) (Riet-Correa 2007) and bovine viral diarrhea (BVDV) (Pavarini et al. 2008) viruses. The Border Disease, Cache Valley (Radostits et al. 2000), and Akabane (Konno \& Nakagawa 1982) viruses have not been detected in Brazil so far. These diseases can be discarded in the present study since pregnant cows that were in the same properties and did not ingest apple pomace bred healthy calves. There are no reports of osseous malformation associated with ingestion of apple pomace in Brazil. In other countries, this condition has been observed in calves born of cows that fed on this by-product, corn silage, and non-protein nitrogen (NNP) (Bovard et al. 1977, Rumsey et al. 1977). Although the etiology of these malformations has not been defined, Valero et al. 1990 suggested that manganese deficiency may produce osseous malformation in calves, and the low concentration of manganese in apple pulp may be the cause of these malformations. According to Rumsey et al. 1977, these malformations may also be associated with agrochemicals frequently used in apple culture, which may remain as residue in the bagasse. The National Agency of Sanitary Surveillance (Anvisa 2016) lists over 60 different types of pesticides for pest control in apple crops, including carbamates and organophosphates, which are cholinesterase inhibitors and lipophilic insecticides widely used in the control of pests in animals and plants. Their solubility characteristics facilitate their excretion through milk and passage through the placental barrier. Exposure of neonates to these insecticides at concentrations that do not show clinical signs of maternal systemic intoxication can cause harm to the developing individual (Grecco et al. 2009, Oliveira-Filho et al. 2010). Another product often used in apple trees is abamectin, which is also used as parasiticide in animals and, at doses higher than indicated, can produce neurological changes and death in cattle (Seixas et al. 2006).

Congenital defects may also occur as a result of consumption of plants. According to Dantas et al. (2010), Mimosa tenuiflora leads to facial malformation with bragnatia, cleft lip and palate, corneal opacity, arthrogryposis, scoliosis, and lordosis in ruminants in northeast Brazil. Other malformations might occur in calves born to cows that ingest Lupinus sp., Nicotiana glauca, and Nicotiana tabacum, and fetuses may show signs of torticollis, arthrogryposis, scoliosis, excessive flexion of the carpus, lordosis, cleft palate, and head deformity (Kellerman et al. 1990, Panter et al. 1998). Ingestion of Veratrum californicum by sheep during the $14^{\text {th }}$ day of gestation will result in lambs with cyclopia, holoprosencephaly, and absence of the pituitary gland, after the $14^{\text {th }}$ day of gestation, results in several skeletal anomalies and palatine clefts (Zachary 2018); ingestion of Conium maculatum causes arthrogryposis, among other clinical signs (Tokarnia et al. 1985, 2012). None of these teratogenic plants were found in the properties where the outbreaks occurred.

\section{CONCLUSION}

Pregnant cows fed apple pomace at the dose of $20-30 \mathrm{~kg} / \mathrm{animal} /$ day during the gestational period may breed calves with osseous malformations. When these changes are less severe, calves can evolve to improved clinical conditions, but reach adult age with reduced size.

Conflict of interest statement. - The authors declare that there are no conflicts of interest.

\section{REFERENCES}

Anvisa 2016. Programa de análise de resíduos de agrotóxicos em alimentos, (PARA). Available at <http://portal.anvisa.gov.br/documents/111215/0/ Relat\%C3\%B3rio+PARA+2013-2015_VERS\%C3\%83은.pAL.pdf/494cd7c55408-4e6a-b0e5-5098cbf759f8> Accessed on Nov. 9, 2017.

Bovard K.P., Rumsey T.S., Oltjen R.R., Fontenot J.P. \& Priode B.M. 1977. Supplementation of apple pomace with nonprotein nitrogen for gestating beef cows. II. Skeletal abnormalities of calves. J. Anim. Sci. 45(3):523-531. <http://dx.doi.org/10.2527/jas1977.453523x><PMid:409705>

Dantas A.F.M., Riet-Correa F., Medeiros R.M.T., Galiza G.J.N., Pimentel L.A., Anjos B.L. \& Mota R.A. 2010. Malformações congênitas em ruminantes no 
semiárido do nordeste brasileiro. Pesq. Vet. Bras. 30(10):807-815. <http:// dx.doi.org/10.1590/S0100-736X2010001000002>

Grecco F.B., Schild A.L., Soares M.P., Raffi M.B., Sallis E.S.V. \& Damé M.C. 2009. Intoxicação por organofosforados em búfalos (Bubalus bubalis) no Rio Grande do Sul. Pesq. Vet. Bras. 29(3):211-214.<http://dx.doi.org/10.1590/ S0100-736X2009000300004>

Kellerman T.S., Coetzer J.A.W. \& Naudé T.W. 1990. Neurological disorders without notable pathological lesions, p.47-82. In: Ibid. (Eds), Plant Poisonings and Mycotoxicoses of Livestock in Southern Africa. 2nd ed. Oxford, Cape Town.

Kennedy M., List D., Lu Y. \& Foo L.Y. 1999. Apple pomace and products derived from apple pomace: uses, composition and analysis, p.75-119. In: Linskens H.F. \& Jackson J.F. (Eds), Modern Methods of Plant Analyses, Analysis of Plant Waste Materials. Vol.20. Springer Verlag, Berlin. <http:// dx.doi.org/10.1007/978-3-662-03887-1_4>.

Konno S. \& Nakagawa M. 1982. Akabane disease in cattle: congenital abnormalities caused by viral infection. Experimental Disease. Vet. Pathol. 19(3):267-279. <http://dx.doi.org/10.1177/030098588201900305> $<$ PMid:7200279>

Latter M.R., Latter B.H.D., Wilkins J.F. \& Windsor P.A. 2006. Inheritance of proportionate dwarfism in Angus cattle. Austin Vet. J. 84(4):122-128. <http:// dx.doi.org/10.1111/j.1751-0813.2006.tb13394.x><PMid:16629191>

Manterola H., Cerda A.D. \& Mira J.J. 1999. Los residuos agrícolas y su uso en la alimentación de ruminantes. Ministerio de Agricultura y Fundación para la Innovación Agraria. Santiago, Chile. 222p.

Marcolongo-Pereira C., Schild A., Soares M.P., Vargas Jr S.F. \& Riet-Correa F. 2010. Defeitos congênitos diagnosticados em ruminantes na região sul do Rio Grande do Sul. Pesq. Vet. Bras. 30(10):816-826. <http://dx.doi. org/10.1590/S0100-736X2010001000003>

Oliveira-Filho J.C., Carmo P.M.S., Pierezan F., Tochetto C., Lucena R.B., Rissi D.R. \& Barros C.S.L. 2010. Intoxicação por organofosforado em bovinos no Rio Grande do Sul. Pesq. Vet. Bras. 30(10):803-806. <http://dx.doi. org/10.1590/S0100-736X2010001000001>

Panter K.E., Gardner D.R., Shea R.E., Molyneux R.J. \& James L.F. 1998. Toxic and teratogenic piperidine alkaloids from Lupinus, Conium, and Nicotiana species, p.345-350. In: Garland T. (Ed.), Toxic Plants and Other Natural Toxicants. CAB International, New York.

Pavarini S.P., Sonne L., Antoniassi N.A.B., Santos A.S., Pescador C.A., Corbellini L.G. \& Driemeier D. 2008. Anomalias congênitas em fetos bovinos abortados no sul do Brasil. Pesq. Vet. Bras. 28(3):149-154.

Prophet E.B., Mills B., Arrington J.B. \& Sobin L.H. 1992. Laboratory methods in histotechnology. American Registry of Pathology, Armed Forces Institute of Pathology, Washington, DC. 274p.
Radostits O.M., Gay C.C., Blood D.C. \& Hinchcliff K.W. 2000. Veterinary Medicine. 9th ed. W.B. Saunders, Edinburgh, p.938-940.

Riet-Correa F. 2007. Língua azul, p.169-173. In: Riet-Correa F., Schild A.L., Lemos R.A.A. \& Borges J.R.J. (Eds), Doenças de Ruminantes e Equídeos. Vol.1. $3^{\mathrm{a}}$ ed. Varela, São Paulo.

Rumsey T.S., Bovard K.P., Fontenot J.P., Oltjen R.R. \& Priode B.M. 1977. Supplementation of apple pomace with nonprotein nitrogen for gestating beef cows. IV. Pesticide accumulation. J. Anim. Sci. 45(3):543-550.<http:// dx.doi.org/10.2527/jas1977.453543x $><$ PMid:578509>

Schild A.L. 2007. Defeitos congênitos, p.30-32. In: Riet-Correa F., Schild A.L., Méndez M.C., Lemos R.A.A. \& Borges J.R.J. (Eds), Doenças de Ruminantes e Equídeos. Vol.1. 3a ed. Varela, São Paulo.

Seixas J.N., Peixoto P.V., Armién A.G., Jabour F.F. \& Brito M.F. 2006. Aspectos clínicos e patogenéticos da intoxicação por abamectina em bezerros. Pesq. Vet. Bras. 26(3):161-166. <http://dx.doi.org/10.1590/S0100736X2006000300006>

Thompson K. 2007. Bones and joints, p.1-184. In: Maxie M.G. (Ed.), Jubb, Kennedy and Palmer's Pathology of Domestic Animals. Vol.1. 5th ed. Saunders Elsevier, Philadelphia.

Tokarnia C.H., Dobereiner J. \& Peixoto P.V. 1985. Intoxicação experimental por Conium maculatum (Umbeliferae) em bovinos e ovinos. Pesq. Vet. Bras. 5(1):15-25.

Tokarnia C.H., Brito M.F., Barbosa J.D., Peixoto P.V. \& Döbereiner J. 2012. Plantas Tóxicas do Brasil para Animais de Produção. 2ª ed. Helianthus, Rio de Janeiro, p.392-395.

Valero G., Alley M.R., Badcoe L.M., Manktelow B.W., Merrall M. \& Lawes G.S. 1990. Chondrodystrophy in calves associated with manganese deficiency. N. Z. Vet. J. 38(4):161-167. <http://dx.doi.org/10.1080/00480169.1990 .35645> <PMid:16031605>

White P.J. \& Windsor P.A. 2012. Congenital chondrodystrophy of unknown origin in beef herds. Vet. J. 193(2):336-343. <http://dx.doi.org/10.1016/j. tvjl.2012.04.016><PMid:22633829>

White P.J., Ward M.P., Toribio J.A.L.M.L. \& Windsor P.A. 2010a. The association between congenital chondrodystrophy of unknown origin (CCUO) in beef cattle and drought in south-eastern Australia. Prev. Vet. Med. 94(3/4):178-184. <http://dx.doi.org/10.1016/j.prevetmed.2010.02.002><PMid:20223538>

White P.J., Windsor P.A., Dhand N.K. \& Toribio J.A.L.M.L. 2010b. Risk factors for congenital chondrodystrophy of unknown origin in beef cattle herds in southeastern Australia. Prev. Vet. Med. 96(1/2):36-48. <http://dx.doi. org/10.1016/j.prevetmed.2010.05.011><PMid:20638972>

Zachary J.F. 2018. Bases da Patologia em Veterinária. 6aㅡ ed. Elsevier, Rio de Janeiro, p.1005, p.1179-1180. 